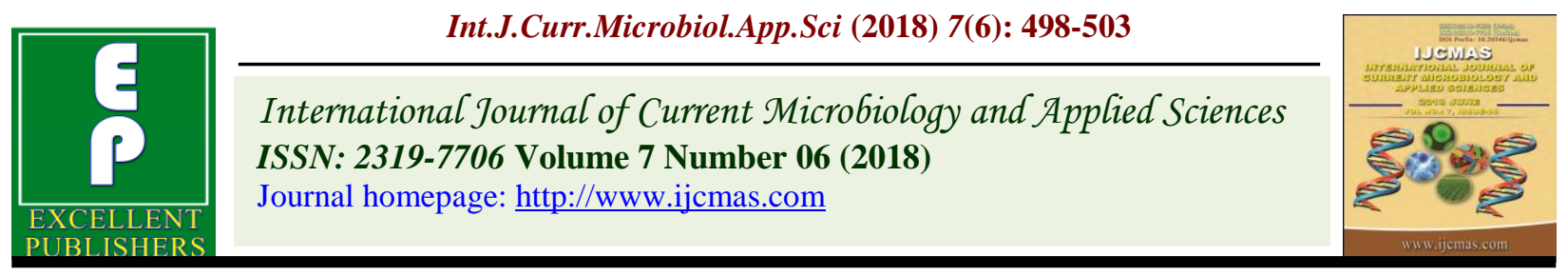

Original Research Article

https://doi.org/10.20546/ijcmas.2018.706.055

\title{
Effect of Foliar Spray of Micro-Nutrients on Pigment Content in Pot Mum Cultivars Ajina Purple and Dolly White
}

\author{
Jagdish Patidar*, M. Vidhya Sankar and S.N. Mishra \\ Department of Floriculture and Landscaping, K.N.K. College of Horticulture, \\ Mandsaur-458001 (Madhya Pradesh), India \\ *Corresponding author
}

A B S T R A C T

\begin{tabular}{|l|}
\hline K e y w o r d s \\
$\begin{array}{l}\text { Foliar Spray, Micro- } \\
\text { Nutrients, Ajina Purple } \\
\text { and Dolly White }\end{array}$ \\
\hline Article Info \\
\hline $\begin{array}{l}\text { Accepted: } \\
\text { 04 May } 2018 \\
\text { Available Online: } \\
\text { 10 June 2018 }\end{array}$ \\
\hline
\end{tabular}

\section{Introduction}

Chrysanthemum has been considered number one among the major pot crops and year round pot mums are now grown all over the world. Pot mum production has become the most profitable form of commercial chrysanthemum growing. Economy of time, space and material has made this style of growing very promising. An excellent range of colour, form, long lasting quality of blooms and ease of handling make them most popular. The bright, colourful flowers provide a wide range of sales opportunities to garden centres, supermarkets, home improvement stores and mass market outlets. Availability of micronutrients from soil to the plants is affected by type of soil, ambient temperature, moisture condition of soil (Rao, 2005), soil pH, and nature of soil, so foliar application is more effective for nutrient uptake of plants.

Micronutrients play many vital roles in plant nutrition uptake, but most of them are used in the functioning of a number of enzyme systems. However, there is considerable variation in the specific functions of the various micronutrients in plants and in microbial growth processes. Nowadays micronutrients are gradually gaining momentum among the flower growers because of their beneficial nutrient support and at the same time to ensure better harvest and return (Balakrishnan et al., 2007). Micronutrients assist in nitrogen assimilation and synthesis of protein (Kumar et al., 2003). Micronutrients 
have a great bearing in influencing the yield attributes and flower production. Application of micronutrients is found to enhance the foliage and flower production. Micronutrients activate several enzymes and are involved in various physiological activities (Sinha et al., 1999).

\section{Materials and Methods}

One healthy rooted cutting was planted in one pot. Before planting the roots were dipped in carbendazim $3 \mathrm{~g} /$ litre of water, for 10 minutes. Plants were planted at the centre of the pots, watering was done and pots were kept in shade. Micro-nutrients (Fe-EDTA, Zn-EDTA, Mn-EDTA and Borax) spray was done three times. The first stage was active vegetative growth (30 DAP), the second at bud initiation stage (50 DAP) and the third at peak flowering (90 DAP).

\section{Determination of chlorophyll content}

Prepare $80 \%$ acetone. Grind the known weight pieces of plant material (avoid mid ribs) in mortar and pestle using $5 \mathrm{ml}$ of $80 \%$ acetone. Filter the homogenate in $25 \mathrm{ml}$ volumetric flask by using Whatman filter paper grade-1. Wash out the homogenate 3-4 times with $5 \mathrm{ml}$ of $80 \%$ acetone each time. Grind the tissue once again with minimum quantity of acetone if required as it helps in complete extraction of plant pigments. Centrifuge the tubes (2000 rpm) for 10 minutes. Collect the supernatant in $25 \mathrm{ml}$ volumetric flask and make up the volume with $80 \%$ acetone.

Record the absorbance of supernatant at two different wavelengths (663 and $645 \mathrm{~nm}$ ) using spectrophotometer by keeping $80 \%$ acetone as blank.

The amount of total chlorophyll is determined using the following formula given by Arnon (1949).

\author{
12.7 (A 663) - 2.69 (A 645) \\ Chlorophyll “a” = -------------- $\times$ V \\ 22.9 (A 645) - 4.68 (A 663) \\ Chlorophyll " $\mathrm{b}$ " = ------------- $\times$ V \\ Total Chlorophyll = Chlorophyll "a" + \\ Chlorophyll "b"
}

Where,

A: optical density

a: length of light path in cell

w: weight of sample ( $g$ )

$\mathrm{V}$ : volume of solution

\section{Determination of anthocynin pigment}

Grind a known weight of fresh plant material in alcohol then filter or centrifuge and collect the extract. Pipette $1 \mathrm{ml}$ of the alcohol extract into the test tube and add $3 \mathrm{ml}$ or HCI in aqueous methanol. Add $1 \mathrm{ml}$ of anthocyanin reagents to the samples. Prepare the blank in the same manner by adding $1 \mathrm{ml}$ of methanolHQ instead of anthocyanin reagent. After 15 min of incubation in the dark, measure the absorbance at $525 \mathrm{~nm}$ against the blank. Calculate the amount of anthocyanins present in the sample from a standard curve prepared with cyanin hydrochloride.

\section{Determination of leuco-anthocynin pigment}

Grind a known weight of tissue in methanol or ethanol filter or centrifuge and collect the supernatant. Pipette $1 \mathrm{ml}$ of the extract in to a test tube. Reduce the volume to $0.5 \mathrm{ml}$ on a hot water bath so that the sample does not contain more than $0.5 \mathrm{ml}$ of methanol or ethanol. Add $0.5 \mathrm{ml}$ of water and $10 \mathrm{ml}$ of leuco-anthocyanin reagent and mix thoroughly. Heat the tubes in a water bath at $97 \pm 1^{\circ} \mathrm{C}$ for $3 \mathrm{~min}$ without covering the tubes. Cover the tubes with glass stoppers and 
continue heating for a total of $40 \mathrm{~min}$. Cool under a running tap. Maintain the blank similarly with the extract but without heating. Measure the absorbance at $550 \mathrm{~nm}$ a colorimeter and express the results as $\mathrm{A}_{550}$ values.

\section{Procedure follows in determination Leaf nutrient content}

\section{Materials required}

Dried plants, $\mathrm{H}_{2} \mathrm{SO}_{4}, \mathrm{HClO}_{4}$, double distilled water, willymill, funnels, Whatman filter papers grade 1, volumetric flasks, measuring cylinders, pipettes, AAS (Hitachi Z-2300) etc.

\section{Procedure}

Dried plants were harvested. The root portion was removed and plants were dried in hot air oven on $75{ }^{0} \mathrm{C}$ for 24 hours. Dried samples were ground in willymill and dried powder was used for analysis. $1.0 \mathrm{~g}$ dried powder was digested in di-acid mixture $15 \mathrm{ml}$ $\left(\mathrm{H}_{2} \mathrm{SO}_{4}: \mathrm{HClO}_{4}, 4: 1\right)$ at the temperature of 350$400^{\circ} \mathrm{C}$ using Kel-plus KES-12 furnace. After complete digestion the digested extract was diluted with double distilled water up to 50 ml. Diluted extract was analyzed for micronutrients on AAS (Hitachi Z-2300).

\section{Results and Discussion}

\section{Chlorophyll content before and after flowering}

It can be observed that the mean total chlorophyll content before flowering was more in V1 $(1.19 \mathrm{mg} / \mathrm{g})$ in comparison to V2 $(1.84 \mathrm{mg} / \mathrm{g})$, whereas after flowering it was more in V2 $(1.77 \mathrm{mg} / \mathrm{g})$ than V1 $(1.76 \mathrm{mg} / \mathrm{g})$. Among the different micronutrient sprays under studyT1 sprays recorded the highest total chlorophyll content before and after flowering it was $(2.20 \mathrm{mg} / \mathrm{g}$ and $2.12 \mathrm{mg} / \mathrm{g}$ ) respectively followed by $\mathrm{T} 2(2.19 \mathrm{mg} / \mathrm{g}$ and $2.07 \mathrm{mg} / \mathrm{g}$ ). While the total lowest chlorophyll content $(1.00 \mathrm{mg} / \mathrm{g}$ and $0.69 \mathrm{mg} / \mathrm{g})$ respectively recorded by $\mathrm{T} 11$ (Control). The treatment combination T1V1 spray recorded the highest total chlorophyll content before and after flowering $(2.23 \mathrm{mg} / \mathrm{g}$ and $2.18 \mathrm{mg} / \mathrm{g})$ followed by T2V1 $(2.21 \mathrm{mg} / \mathrm{g})$ and T2V2 $(2.12$ $\mathrm{mg} / \mathrm{g}$ ) before and after flowering. The total lowest chlorophyll content before and after flowering was recorded by T11V2 $(0.84 \mathrm{mg} / \mathrm{g}$ and $0.65 \mathrm{mg} / \mathrm{g}$ ). This is an important consideration since iron is associated with chlorophyll formation and is a constituent of several plant compounds and enzymes as they are involved in energy producing and utilizing process in the plant and is important in many redox reactions (Pratap et al., 2005). This may be due to indirect role of iron in chlorophyll Bio-synthesis iron play a very important role in chlorophyll synthesis and pigmentation. The above findings are in close agreement with finding of Balakrishnan et al., (2007) in marigold.

\section{Anthocynin and leuco anthocynin}

It can be observed from table 1 that the mean anthocyanin content in petals of V1 was $0.78 \mathrm{mg} / \mathrm{g}$ and leuco anthocynin content was V2 $(0.71 \mathrm{mg} / \mathrm{g})$. The highest anthocynin content $(0.86 \mathrm{mg} / \mathrm{g})$ was recorded by $\mathrm{T} 1 \& \mathrm{~T} 3$ followed by $\mathrm{T} 2(0.83 \mathrm{mg} / \mathrm{g})$ whereas total leuco-anthocynin content $0.82 \mathrm{mg} / \mathrm{g}$ was recorded by $\mathrm{T} 3$ followed by $\mathrm{T} 1(0.79 \mathrm{mg} / \mathrm{g})$. The lowest anthocynin and leuco anthocynin content was recorded by $\mathrm{T} 11(0.66 \mathrm{mg} / \mathrm{g}$ and $0.55 \mathrm{mg} / \mathrm{g}$ ) respectively. Increase in pigment content due to the micronutrients ( $\mathrm{Fe}$ and $\mathrm{Zn}$ ) activate several enzymes (catalase, peroxidase, alcohol, dehydrogenase, carbonic dehydrogeniase and tryptophan synthatase, etc.) and involved themselves in chlorophyll synthesis and various physiological activities (Kumar and Haripriya, 2010). 
Table.1 Effect of Micro-nutrient on chlorophyll, anthocynin and leuco-anthocynin content in pot-mum

\begin{tabular}{|c|c|c|c|c|c|c|c|c|c|c|}
\hline \multirow[t]{2}{*}{ Treatment } & \multicolumn{3}{|c|}{$\begin{array}{l}\text { Chlorophyll content in } \\
\text { leaves before } \\
\text { flowering }(\mathrm{mg} / \mathrm{g})\end{array}$} & \multicolumn{3}{|c|}{$\begin{array}{l}\text { Chlorophyll content in } \\
\text { leaves before } \\
\text { flowering ( } \mathrm{mg} / \mathrm{g})\end{array}$} & \multicolumn{2}{|c|}{$\begin{array}{l}\text { Anthiocyanin } \\
\text { content } \\
\text { (mg/g) }\end{array}$} & \multicolumn{2}{|c|}{$\begin{array}{l}\text { Leuco- } \\
\text { Anthiocyanin } \\
\text { content } \\
(\mathrm{mg} / \mathrm{g})\end{array}$} \\
\hline & V1 & V2 & Mean & V1 & V2 & Mean & & & & 2 \\
\hline $\mathrm{T} 1(\mathrm{Fe}-0.4 \%)$ & 2.23 & 2.16 & 2.20 & 2.18 & 2.06 & 2.12 & & & & 79 \\
\hline $\mathrm{T} 2(\mathrm{Fe}-0.8 \%)$ & 2.21 & 2.17 & 2.19 & 2.02 & 2.12 & 2.07 & & & & 74 \\
\hline T3 (Zn-0.4\%) & 1.96 & 1.98 & 1.97 & 1.88 & 1.90 & 1.89 & & & & 82 \\
\hline T4 (Zn-0.8\%) & 2.19 & 2.11 & 2.15 & 2.11 & 2.03 & 2.07 & & & & 75 \\
\hline T5 (Mn-0.4\%) & 1.91 & 1.87 & 1.89 & 1.86 & 1.81 & 1.84 & & & & 76 \\
\hline T6 (Mn-0.8\%) & 1.94 & 1.90 & 1.92 & 1.53 & 1.81 & 1.67 & & & & 68 \\
\hline $\begin{array}{l}\text { T7 } \\
0.2 \%)\end{array}$ & 1.94 & 1.89 & 1.92 & 1.81 & 1.82 & 1.81 & & & & 69 \\
\hline $\begin{array}{l}\text { T8 } \\
\mathbf{0 . 4 \%} \text { (Borex- }\end{array}$ & 1.77 & 1.63 & 1.70 & 1.65 & 1.59 & 1.62 & & & & 64 \\
\hline $\begin{array}{l}\text { T9 }(\mathrm{Fe}+\mathrm{Zn}+\mathrm{Mn}- \\
0.4 \%+\text { Borex- } \\
0.2 \%)\end{array}$ & 1.82 & 1.84 & 1.83 & 1.74 & 1.78 & 1.76 & & & & 73 \\
\hline $\begin{array}{l}\mathrm{T} 10 \\
(\mathrm{Fe}+\mathrm{Zn}+\mathrm{Mn}- \\
0.8 \%+\text { Borex- } \\
0.4 \%)\end{array}$ & 1.94 & 1.88 & 1.91 & 1.92 & 1.83 & 1.88 & & & & 66 \\
\hline T11 (Control) & 1.16 & 0.84 & 1.00 & 0.72 & 0.65 & 0.69 & & & & 55 \\
\hline Mean For factor & 1.91 & 1.84 & 1.88 & 1.76 & 1.77 & 1.76 & & & & 71 \\
\hline Factor & V & $\mathbf{T}$ & $\mathbf{V} * \mathbf{T}$ & V & $\mathbf{T}$ & $\mathbf{V} * \mathbf{T}$ & $\mathbf{V}$ & $\mathbf{T}$ & $\mathbf{V}$ & $\mathbf{T}$ \\
\hline S.E (m)+ & 0.03 & 0.08 & 0.11 & 0.04 & 0.09 & 0.13 & 0.007 & 0.017 & 0.007 & 0.015 \\
\hline CD at $5 \%$ & NS & 0.24 & NS & NS & 0.26 & NS & 0.021 & 0.050 & 0.019 & 0.045 \\
\hline
\end{tabular}

V1= Ajina Puple, V2= Dolly White 
Table.2 Effect of micro-nutrient on leaf nutrient content

\begin{tabular}{|c|c|c|c|c|c|c|c|c|c|}
\hline \multirow[t]{2}{*}{ Treatment } & \multicolumn{3}{|c|}{$\mathbf{Z n}$} & \multicolumn{3}{|c|}{$\mathrm{Fe}$} & \multicolumn{3}{|c|}{ Mn } \\
\hline & V1 & V2 & Mean & V1 & V2 & Mean & V1 & V2 & Mean \\
\hline $\mathrm{T} 1(\mathrm{Fe}-0.4 \%)$ & 1.67 & 1.28 & 1.48 & 1.69 & 1.30 & 1.50 & 0.79 & 0.79 & 0.79 \\
\hline $\mathrm{T} 2(\mathrm{Fe}-0.8 \%)$ & 1.83 & 1.73 & 1.78 & 1.97 & 1.76 & 1.86 & 0.76 & 0.74 & 0.75 \\
\hline T3 (Zn-0.4\%) & 1.70 & 1.64 & 1.67 & 1.72 & 1.66 & 1.69 & 0.67 & 0.82 & 0.74 \\
\hline T4 (Zn-0.8\%) & 1.71 & 1.66 & 1.69 & 1.72 & 1.68 & 1.70 & 0.81 & 0.75 & 0.78 \\
\hline T5 (Mn-0.4\%) & 1.46 & 1.45 & 1.46 & 1.45 & 1.45 & 1.45 & 0.80 & 0.78 & 0.79 \\
\hline T6 (Mn-0.8\%) & 1.01 & 1.64 & 1.33 & 0.99 & 1.61 & 1.30 & 0.71 & 0.68 & 0.69 \\
\hline T7 (Borex-0.2\%) & 1.18 & 1.31 & 1.25 & 0.98 & 1.31 & 1.14 & 0.80 & 0.69 & 0.75 \\
\hline T8 (Borex-0.4\%) & 0.97 & 1.27 & 1.12 & 0.98 & 1.26 & 1.12 & 0.78 & 0.64 & 0.71 \\
\hline $\begin{array}{l}\text { T9 } \quad(\mathrm{Fe}+\mathrm{Zn}+\mathrm{Mn}- \\
0.4 \%+\text { Borex }-0.2 \%)\end{array}$ & 1.49 & 1.53 & 1.51 & 1.66 & 1.51 & 1.75 & 0.75 & 0.73 & 0.74 \\
\hline $\begin{array}{l}\text { T10 } \quad(\mathrm{Fe}+\mathrm{Zn}+\mathrm{Mn}- \\
0.8 \%+\text { Borex }-\mathbf{0 . 4 \%})\end{array}$ & 1.55 & 1.67 & 1.61 & 1.41 & 1.37 & 1.98 & 0.78 & 0.66 & 0.72 \\
\hline T11 (Control) & 0.93 & 0.95 & 0.94 & 0.92 & 0.94 & 0.93 & 0.66 & 0.55 & 0.60 \\
\hline Mean For factor & 1.41 & 1.47 & & 1.41 & 1.44 & & 0.75 & 0.71 & \\
\hline Factor & $\mathbf{V}$ & $\mathbf{T}$ & $\mathbf{V} * \mathbf{T}$ & $\mathbf{V}$ & $\mathbf{T}$ & $\mathbf{V} * \mathbf{T}$ & $\mathbf{V}$ & $\mathbf{T}$ & V*T \\
\hline S.E (m)+ & 0.05 & 0.11 & 0.15 & 0.05 & 0.12 & 0.16 & 0.01 & 0.03 & 0.04 \\
\hline CD at $5 \%$ & NS & 0.33 & NS & NS & 0.33 & NS & 0.03 & 0.08 & 0.11 \\
\hline
\end{tabular}

V1= Ajina Puple, V2= Dolly White

Iron plays a very important role in chlorophyll synthesis and pigmentation (Naik et al., 2008).

\section{Leaf nutrient content}

It can be observed from table 2 above finding that mean $\mathrm{Zn}$ and $\mathrm{Fe}$ content was more in V2 (1.47 ppm and $1.44 \mathrm{ppm}$ ) in comparison to V1 (1.41 ppm) whereas the mean Mn content was more in V1 $(0.75 \mathrm{ppm})$ then $\mathrm{V} 2$ $(0.71 \mathrm{ppm})$ Among the different nutrient sprays under study $\mathrm{T} 2$ recorded the highest $\mathrm{Zn}$ and $\mathrm{Fe}(1.78 \mathrm{ppm}$ and $1.86 \mathrm{ppm})$ followed by T3 which were recorded (1.67 ppm and 1.69 ppm) while the highest Mn content under different micro-nutrient sprays $\mathrm{T} 1$ and $\mathrm{T} 5$ contain $0.79 \mathrm{ppm}$. The lowest $\mathrm{Zn}, \mathrm{Fe}$ and $\mathrm{Mn}$ content in leaves was recorded by T11 (0.94 ppm $\mathrm{Zn}, 0.93 \mathrm{ppm} \mathrm{Fe}$ and $0.60 \mathrm{ppm} \mathrm{Mn),}$ under the different treatment combination T2V1 was recorded the highest $\mathrm{Zn}$ and $\mathrm{Fe}$ content (1.83 ppm1.97 ppm) followed by T2V2 (1.73ppm and $1.76 \mathrm{ppm})$ and T4V1 content highest Mn $0.81 \mathrm{ppm}$.

The lowest $\mathrm{Zn}$ and Fe content was recorded by treatment combination T11V1 $(0.93 \mathrm{ppm}$ and $0.92 \mathrm{ppm}$ ) whereas the lowest Mn content was recorded by T11V2 (0.55 ppm). Micronutrients $(\mathrm{Fe}, \mathrm{Zn}$ and $\mathrm{Mn}$ ) are co-factor for several enzymes (Cytochromes, Peroxidase, Catalase, Ferodoxin, Alcohol dehydrogenase, Arginase, phosphotransferase, carbonic anhydrase and carboxy peptidase, etc.) and involved themselves in chlorophyll synthesis and various physiological activities. These results are in accordance with the finding of Pratap et al., (2005).

\section{References}

Arnon, D.J. (1949). Copper enzymes in isolated chloroplasts, polyphenoxidases 
in Beta vulgaris. Plant physiology, 24: $\mathrm{p}$ $1-15$.

Balakrishnan, V., Jawaharlal, M., Kumar, T. S., and Ganga, M. (2007). Response of micro-nutrients on flowering, yield and xanthophyll content in African marigold (Tagetes erecta L.). J. of Ornamental Hort., 10 (3): 153-156.

Kumar, J. Mir, A. and Singh, P. V. (2003). Effect of Mn and Zn Sprays on carnation. J. of Ornamental Horticulture, 6 (1): 83.

Kumar, S. and Haripriya, K. (2010). Effect of foliar application of iron and zinc on growth, flowering and yield of nerium (Nerium odorum L.). Plant Archives, 10 (2): 637

Naik, D. V., Dhaduk, B. K., Singh, A. and Jhambal, S. S. (2008). Effect of different micronutrients on growth and flowering of gladiolus cv. American Beauty. The Horticulture Journal, 21(1): 50-52.

Pratap, M., Reddy, S. A. and Reddy, Y. N. (2005). Response of pre-harvest micronutrient foliar spray on leaf nutrients and corm production in gladiolus. J. of Ornamental Horticulture, 8 (1): $18-22$.

Rao, K. S. P. (2005). Influence of iron nutrition on growth, flowering and corm yield in gladiolus. J. of Ornamental Horticulture, 8 (4): 293-295.

Sinha, A. K., Singh, C. and Jain, B. P. (1999). Effect of plant growth substances and nutrients on fruit set, fruit drop, fruit retention and cracking of Litchi cv. Purbi. Indian Journal of Horticulture, 56 (4): 309-311.

\section{How to cite this article:}

Jagdish Patidar, M. Vidhya Sankar and Mishra, S.N. 2018. Effect of Foliar Spray of MicroNutrients on Pigment Content in Pot Mum Cultivars Ajina Purple and Dolly White. Int.J.Curr.Microbiol.App.Sci. 7(06): 498-503. doi: https://doi.org/10.20546/ijcmas.2018.706.055 